\title{
Socio-Economic Impacts of the Common Fisheries Policy on South and Central Tyrrhenian Sea (GSA 10) Demersal Trawl Fisheries
}

\author{
Rosaria Felicita Sabatella ${ }^{(凶)}$, Paolo Accadia, Maria Cozzolino, \\ Monica Gambino, Loretta Malvarosa, and Evelina Carmen Sabatella \\ NISEA Fisheries and Aquaculture Economic Research, Salerno, Italy \\ r.sabatella@nisea.eu
}

\begin{abstract}
European and national fisheries policies aim at reverting toa sustainable exploitation of fish resources and to ensure the economic and social sustainability of fishing activities in the medium to long term (Art. 2 of Regulation [EU] No. 1380/2013).

The aim of this study was to assess the socio-economic impact of national and European management measures, implemented in the past ten years, on demersal trawl fisheries in South and Central Tyrrhenian Sea (GSA 10).

An effectiveness and efficiency evaluation was performed to establish whether the objectives of the management policies were achieved (effectiveness) and at what cost (efficiency).

The economic and social effectiveness of the measures of the Italian management plans showed a limited performance, particularly in economic terms, due substantially to reduced landings, increased operating costs and reduced labour productivity. The efficiency assessment, which involved analysis of the results of the EU cohesion policy financed by the structural funds, demonstrated that despite the considerable financial out lay the measures failed to mitigate the economic and social impact of the Common Fisheries Policy.
\end{abstract}

Keywords: Common Fisheries Policy $\cdot$ Socio-economic impact $\cdot$ Demersal trawl fisheries

\section{Evolution of the Main Demersal Trawl Fisheries Management Measures}

In 1982, Act of 17 February 1982, No. 41, approving the "Plan for the rationalization and development of marine fisheries", introduced a first comprehensive framework for the management of fishing activities. Forty years on, the objective of Art.1- to promote the rational utilization and enhancement of marine biological resource through an equal development of sea fishing - is still topical. The Act laid the foundation of a system based on effort regulation, an approach that has been considered as the most appropriate for its features of Italian as well as Mediterranean fisheries and which has characterized their management for several decades [1]. However, the current state of 
demersal resources demonstrates that effort management through input measures has failed to achieve the expected results $[2,3]$. The adoption of input control measures, which include control of the fishing capacity, can lead to various disadvantages in comparison to regulation through output control; the main disadvantage is that it only addresses one of the components that determine fishing mortality, i.e. capacity. In this case, operators would be inclined to replace the regulated factor with those not subject to control for example by increasing the level of technology used in order to improve catches and reduce the time they require (overcapitalisation and increasing of vessel "catchability") [4]. That approach is now being criticized by the scientific community and the introduction of measures based on output, like the quota system, are suggested also in the Mediterranean Sea [5].

The entry into force of Council Regulation (EC) No. 1967/2006 “Concerning management measures for the sustainable exploitation of fishery resources in the Mediterranean Sea" and of Regulation (EC) No. 1198/2006 was followed in 2008 by the adoption of a new approach based on Management Plans, which the Mediterranean Member States were required to adopt for a number of fishing activities in their waters. The aim of the European Commission was to introduce a national and EU-level multiannual management plan system combining effort management and specific technical measures based on a decentralized decision-making process [6].

The Malta MedFish4Ever Ministerial declaration on the protection of Mediterranean fish resources (30 March 2017) accelerated the adoption of management measures for Italy's demersal stocks. The declaration laid down a detailed work programme for the next 10 years, including the objective of ensuring proper data collection and enhancing the knowledge on stocks to achieve sustainable management of stocks. In June 2019, Regulation (EE) No. 2019/1022 established a multiannual plan for the fisheries exploiting demersal stocks in the western Mediterranean Sea. The first five years of the plan envisage a substantial reduction of fishing activities in terms of days at sea.

\section{Economic and Social Sustainability}

The evaluation of the socio-economic impacts of the Common Fisheries Policy (CFP) on demersal trawl fishing in GSA10 was conducted by selecting appropriate indicators to analyse the economic, social and labour productivity dimensions. The selected indicators are those used in the Italian Management Plans and in Impact Assessment concerning the Commission's proposal for the 2012 reform of the Common Fisheries Policy [7] to evaluate if the objectives have been reached or not.

In particular, the economic sustainability is oriented to increase the long-term resilience of the sector and to encourage fishing on species that produce high price commodities [7]. The economic indicators included: a) medium and long-term profitability in terms of gross profit margin; b) short-term profitability in terms of the ratio of current revenues to break-even point (CR/BEP) and in terms of the value of production and average landing prices, which provide valuable information on market and production trends. 
The social sustainability could be reached increasing the quality of employment (wages, safety and working conditions), making the sector an attractive source of employment and giving alternative development options to coastal communities [7]. The assessment of the social dimension was performed in terms of social stability by using the average cost of labour per employee and employee number. The importance of this indicator relies on the fact that labour remuneration provides purchasing power to the society at large. To this aim it is important to assess if the sector under consideration (the fishing sector in this case) is paying "the right level" of wage to workers. Finally, labour productivity was assessed in terms of gross value added/full-time equivalent (GVA/FTE), which provides information not only on the economic growth and competitiveness of the sector, but also on employee wellbeing. The indicators used for the analysis are listed in Table 1.

Table 1. Indicators used for trend analysis

\begin{tabular}{l|l|l}
\hline Dimension & General aim & Indicators \\
\hline Economic & $\begin{array}{l}\text { To promote the profitability of } \\
\text { the fishing industry }\end{array}$ & $\begin{array}{l}\text { Gross profit margin (medium to long- } \\
\text { term indicator) }\end{array}$ \\
\cline { 2 - 3 } & CR/BEP (short-term indicator) \\
\cline { 2 - 3 } & $\begin{array}{l}\text { To improve sale channel sand } \\
\text { ex-vessel prices }\end{array}$ & $\begin{array}{l}\text { Value of landings } \\
\text { Value of landings/volume of landings }\end{array}$ \\
\hline Social & To promote social stability & Cost of labour/employee \\
\cline { 3 - 3 } & To increase labour productivity & $\begin{array}{l}\text { Gross value added/number of full-time } \\
\text { employees (GVA/FTE) }\end{array}$ \\
\hline
\end{tabular}

Analysis of the trends of the indicators highlighted a substantial decline of longterm profitability (Fig. 1); the gross profit margin and short-term profitability (CR/BEP) showed a slight improvement in the last few years of the series even though they failed to return to the values they had reached before the crisis of 2008. The profit reduction that affected the sector, particularly demersal trawl fisheries, is not merely the consequence of reduced average production, but can also be ascribed to exogenous factors such as increased production costs and sales system in efficiency, which underpin the ever-widening gap between production and consumption prices, all to the benefit of intermediaries [8]. The shrinking employment figures have affected demersal trawl fisheries in a generalized manner. Notably, the loss of job shas been associated with a limited increase in average labour costs, while GVA/FTE highlights a persistently low productivity [9]. 


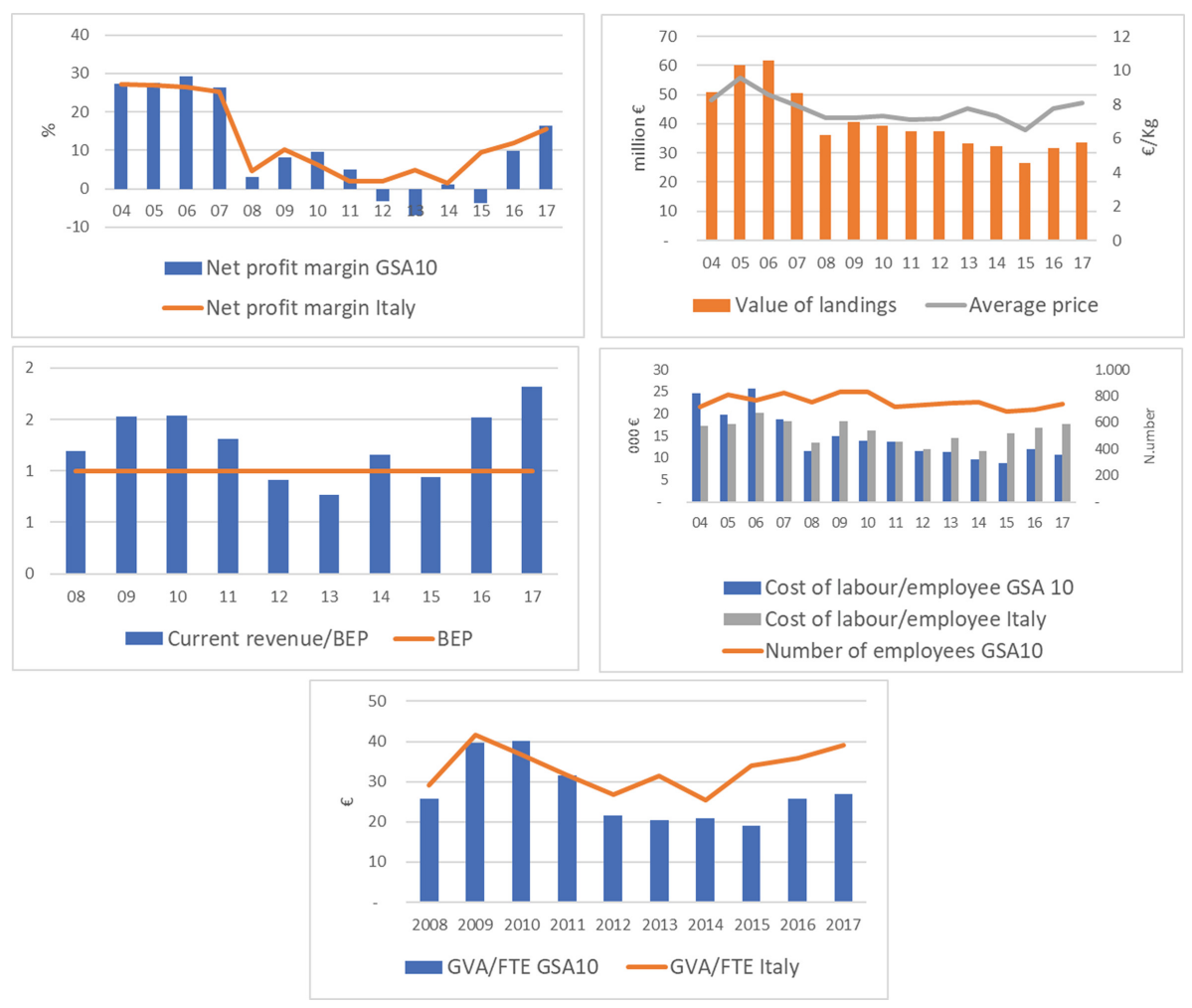

Fig. 1. Demersal trawl fishery indicators, GSA 10

\section{Evaluation of the Effectiveness of the Measures Envisaged by the Italian National Management Plans}

The sustainability objectives - not only environmental but also economic and social are key elements of the national management plans for Italian demersal trawl fisheries. The earliest plans for these fisheries were implemented in 2010 (Director's Decree No. 44 of 17 June2010) [10] and were subsequently updated and implemented in 2011 (Director's Decree of 6 September 2011). Although the first generation of management plans for demersal trawl fisheries should have covered the period 2011-2013, they were extended several times and remained in force until 31 December 2017. The chief measure envisaged by these plans was capacity reduction through vessel decommissioning associated with a range of technical measures like temporary cessation and technical stops, to reduce stock exploitation and promote sustainability. The Director's Decree of 30 January 2018 introduced a new generation of management plans (2018-2023) [11] to address the overexploitation of the remaining stocks, some of which were in even worse condition than before the introduction of the first-generation plans. Again, the measures were substantially based on effort reduction as measured by days at sea. Either generation of management plans set general objectivesboth for the 
economic and the social dimension that were to be achieved viaspecific objectives in the framework ofan integrated management and overall sustainability approach. The economic and social objectives set by the plans are reported in Table 2.

Table 2. General and specific objectives set by the two generations of demersal trawl fisheries management plans (MPs) for the economic and social dimension

\begin{tabular}{l|l|l|l}
\hline MPs & Dimension & General objectives & Specific objectives \\
\hline 2011-2017 & Economic & $\begin{array}{l}\text { To improve the economic } \\
\text { status of fisheries workers }\end{array}$ & $\begin{array}{l}\text { 1. To keep fishery profitability } \\
\text { above the inflation rate }\end{array}$ \\
\cline { 2 - 4 } & Social & $\begin{array}{l}\text { To maximize employment } \\
\text { opportunities in fisheries } \\
\text { areas }\end{array}$ & $\begin{array}{l}\text { 1. Based on the biological } \\
\text { targets, to develop job } \\
\text { opportunities in fisheries-related } \\
\text { activities }\end{array}$ \\
\hline S018-2023 & Economic & $\begin{array}{l}\text { To promote a profitable } \\
\text { fishing industry }\end{array}$ & $\begin{array}{l}\text { 1. To increase fleet profitability } \\
\text { 2. To ensure that current } \\
\text { revenues exceed break-even } \\
\text { revenues }\end{array}$ \\
\cline { 2 - 4 } & Social & $\begin{array}{l}\text { To mitigate the social } \\
\text { impacts of effort reduction }\end{array}$ & $\begin{array}{l}\text { 1. To keep the cost of labour at } \\
\text { the guaranteed minimum wage } \\
\text { 2. To preserve current FTE } \\
\text { employment levels }\end{array}$ \\
\hline
\end{tabular}

\subsection{Evaluation of the Effectiveness of the Management Measures}

Within management policy impact assessment (IA), the ability of a measure to meet management objectives through the management plans is defined as effectiveness. The latest EU guidelines [12] regarding IAs require ex-ante and ex-post evaluation of management measures in terms of effectiveness. Some recent studies have tried to adapt these guidelines to EU-wide fisheries management and have proposed specific indicators -the Target Effectiveness Indicator (TEI) and the Limit Effectiveness Indicator (LEI) -to evaluate the effectiveness of CFP socio-economic measures [13]. The LEI and TEI have recently been employed to assess management measure effectiveness in the framework of the integrated management of coastal areas [14].At present, the ex-post evaluation of results can only be performed for the 2011-2017 plans, since those that came into force in 2018 (and were updated in January 2019) have not yet produced measurable results due to the lack of relevant data. The reference points (RPs) laid down for the first-generation plans should be considered as threshold values (LRPs, Limit Reference Points) and are best analysed by the LEI, which allows assessing whether and to what extent an objective has been met and involves a comparison with baseline data, to provide a measure of the direction of change (Table 3). 
Table 3. Range and interpretation of LEI (Limit Effectiveness Indicator) values

\begin{tabular}{l|l|l}
\hline LEI & $\begin{array}{l}\text { LEI } \\
\text { value }\end{array}$ & Interpretation \\
\hline $\begin{array}{l}\text { LEI }=\mathrm{A} / \mathrm{B} \\
\mathrm{A}=\text { indicator/reference } \\
\text { point }\end{array}$ & LEI $=-1$ & $\begin{array}{l}\text { Worse than both the baseline condition and the } \\
\text { reference point }\end{array}$ \\
\cline { 2 - 3 } $\mathrm{B}=$ indicator/baseline & LEI $=0$ & $\begin{array}{l}\text { Better than the baseline condition but worse than the } \\
\text { reference point }\end{array}$ \\
\cline { 2 - 3 } & LEI $=1$ & $\begin{array}{l}\text { Better than both the baseline condition and the } \\
\text { reference point }\end{array}$ \\
\hline
\end{tabular}

Source: Processing of SOCIOEC data [15].

One or more indicators were developed for each specific objective to measure their achievement. Two indicators identified for two specific objectives, respectively the economic dimension and the social dimension, and their RPs (the \% variation on baseline, calculated as the average value of the indicators in 2004-6) are reported in Table 4.

Table 4. Dimensions, specific objectives, indicators and reference points for the demersal trawl fleet as envisaged by the 2011-2017 national management plans for GSA10

\begin{tabular}{l|l|l|l|l}
\hline Dimension & Specific objective & Indicator & Baseline & $\begin{array}{l}\text { Reference } \\
\text { point }\end{array}$ \\
\hline Economic & $\begin{array}{l}\text { To improve fishing fleet } \\
\text { profitability }\end{array}$ & $\begin{array}{l}\text { Gross profit } \\
\text { per vessel } \\
(€)\end{array}$ & 68,700 & $+86 \%$ \\
\hline Social & $\begin{array}{l}\text { Based on the biological targets, to } \\
\text { develop employment opportunities } \\
\text { in fisheries-related activities }\end{array}$ & $\begin{array}{l}\text { Cost of } \\
\text { labour per } \\
\text { employee } \\
(€)\end{array}$ & 27,500 & $+39 \%$ \\
\hline
\end{tabular}

Source: Processing by NISEA of MiPAAFT data (2011).

For the ex-post evaluation of the socio-economic effects of the management plans 2011-2017 on GSA 10 demersal trawl fisheries, the indicators were calculated and compared to their RPs at three time points of the reference period: 2010 , the year the plans were drawn up (baseline); 2013, their intended expiry date; and 2017, the last effective date after the repeated extension of the plans, and the year the secondgeneration plans were drawn up. The results of the evaluation using the LEI are reported in the next table.

The consistently negative LEI $(-1)$ reflects poor economic and social sustainability and shows that the management plans did not perform well in GSA 10 (Table 5). 
Table 5. Ex-post evaluation of the economic and social effectiveness of the measures of the national management plans 2011-2017 on the demersal trawl fleet operating in GSA 10 using the Limit Effectiveness Indicator (LEI)

\begin{tabular}{c|l|l|l|l|l|l|l|l}
\hline Year & \multicolumn{3}{|l|}{$\begin{array}{l}\text { Economic dimension } \\
\text { Gross profit/vessel }(€)\end{array}$} & \multicolumn{4}{l}{$\begin{array}{l}\text { Social dimension } \\
\text { Cost of labour/employee }(€)\end{array}$} \\
\cline { 2 - 10 } & Baseline & LRP & Outcome & LEI & Baseline & LRP & Outcome & LEI \\
\hline 2010 & 68,700 & 127,782 & 47,399 & -1 & 27,500 & 38,225 & 13,980 & -1 \\
\hline 2013 & 68,700 & 127,782 & 16,349 & -1 & 27,500 & 38,225 & 11,309 & -1 \\
\hline 2017 & 68,700 & 127,782 & 49,796 & -1 & 27,500 & 38,225 & 10,669 & -1 \\
\hline
\end{tabular}

Source: Processing by NISEA of MiPAAFT data (2011) and National Fisheries Data Collection Programme 2010-2017.

The management plans 2018-2023, as updated in January 2019 [11], aim at reducing mortality from fishing $(\mathrm{F})$ in direct proportion to the percent reduction of fishing capacity (2018) and effort (2019-2020). At variance with the first-generation plans, the new plans provide for ex-ante evaluation of the effectiveness of the measures through a simulation of their biological, economic and social effects both in 2020 (the end of the first period of plan implementation and the year when measure effectiveness is to be evaluated) and in 2023 (final year of plan validity).

According to the ex-ante evaluation (Table 6), the management plans 2018-2023 should achieve a fairly satisfactory economic performance, since all the economic indicators included in the simulation show an improvement compared to 2015. As regards social sustainability, the number of FTE jobs is expected to decline as a result of fishing effort reduction.

Table 6. Expected values of the economic and social indicators in 2020 and 2023 and comparison with current situation (demersal trawl fisheries, GSA 10) Source: MiPAAFT (2018).

\begin{tabular}{|c|c|c|c|c|c|c|c|c|c|c|c|c|}
\hline \multirow{2}{*}{$\begin{array}{c}\text { Trawlers 06-24m } \\
\text { GSA10 }\end{array}$} & \multicolumn{4}{|c|}{ Average value 2013-15 } & \multicolumn{4}{|c|}{$\mathbf{2 0 2 0}$} & \multicolumn{3}{c|}{$\mathbf{2 0 2 3}$} \\
\cline { 2 - 11 } & $\begin{array}{c}\text { Gross profit } \\
\text { margin }\end{array}$ & CR/BEP & $\begin{array}{c}\text { Cost of } \\
\text { labour/FTE }\end{array}$ & FTE & $\begin{array}{c}\text { Gross profit } \\
\text { margin }\end{array}$ & $\begin{array}{c}\text { CR/BEP } \\
\text { labour/FTE }\end{array}$ & FTE & $\begin{array}{c}\text { Gross profit } \\
\text { margin }\end{array}$ & $\begin{array}{c}\text { CR/BEP } \\
\text { Cost of } \\
\text { labour/FTE }\end{array}$ & FTE \\
\hline Scenario 0_Status quo & -3.08 & 0.95 & 11,107 & 660 & 7.61 & 1.30 & 11,919 & 648 & 7.67 & 1.30 & 11,913 & 648 \\
\hline Scenario 1_F-5\% & & & & & 11.64 & 1.45 & 16,270 & 456 & 22.83 & 1.85 & 16,188 & 315 \\
\hline
\end{tabular}

\section{Evaluation of the Efficiency of the Management Measures Envisaged by the Italian National Management Plans}

The IA of structural fund efficiency is directed at establishing the adequacy of the public resources allocated to support the sector, i.e. whether the desired effects have been achieved at a reasonable cost [16].

The final results of the two most recent (expired) programmes, FIFG 2000-2006 and EFF 2007-2013, are summarized in the next two paragraphs. 


\subsection{Evaluation of the FIFG 2000-2006 Programme}

Within the FIFG 2000-2006 programme Italy spent a total of $€ 934$ million, accounting for a utilization rate of $88 \%$; about $25 \%$ was used to finance the adjustment of the fishing effort (Priority axis I). The performance indicators identified for the evaluation of the FIFG displayed a positive trend (Table 7). However, the increment of value added per employee was affected less by improved productivity than by the job cuts in the sector, which in 2000-2006 were particularly harsh.

Table 7. Indicators and results of the evaluation of the impact of the FIFG 2000-2006 programme

\begin{tabular}{l|l|l|l}
\hline Indicator & Baseline & Target & $\begin{array}{l}\text { Results on } \\
31 / 12 / 2006\end{array}$ \\
\hline Value added per employee in the fisheries sector & $€ 19,000$ & $\begin{array}{l}20 \% \\
\text { increase }\end{array}$ & $€ 31,000$ \\
\hline $\begin{array}{l}\text { \% Coverage of domestic seafood consumption } \\
\text { with farm products (value and quantity) }\end{array}$ & $\begin{array}{l}9.8 \% \\
\text { (value) }\end{array}$ & $\begin{array}{l}15 \% \text { in } \\
\text { value }\end{array}$ & $\begin{array}{l}12 \% \text { in } \\
\text { value }\end{array}$ \\
\cline { 2 - 4 } & $\begin{array}{l}16.3 \% \text { in } \\
\text { quantity }\end{array}$ & $\begin{array}{l}20 \% \text { in } \\
\text { quantity }\end{array}$ & $\begin{array}{l}19 \% \text { in } \\
\text { quantity }\end{array}$ \\
\hline $\begin{array}{l}\text { \% Coverage of domestic sea food consumption } \\
\text { with preserved products }\end{array}$ & $\begin{array}{l}14.9 \% \text { in } \\
\text { value }\end{array}$ & $\begin{array}{l}18 \% \text { in } \\
\text { value }\end{array}$ & $\begin{array}{l}16 \% \text { in } \\
\text { value }\end{array}$ \\
\cline { 2 - 4 } & $\begin{array}{l}9.1 \% \text { in } \\
\text { quantity }\end{array}$ & $\begin{array}{l}13 \% \text { in } \\
\text { quantity }\end{array}$ & $\begin{array}{l}11 \% \text { in } \\
\text { quantity } \\
(2003)\end{array}$ \\
\hline
\end{tabular}

Source: MIPAAF, EFF Operating Programme (updated April 2010)

Overall, the FIFG measures directed at the fleet proved effective to the extent that they contributed to speed up the capacity reduction, thus making the measure more "acceptable" despite the fact that it affected jobs and social conditions in several areas.

\subsection{Evaluation of the EFF 2007-2013 Programme}

At the end date, the total public outlay accounted for more than $€ 710$ million in terms of commitments, equalling $93 \%$ of the Operative Plan budget; payments were about $€ 690$ million, equal to about $97 \%$. Approximately $44 \%$ of all funds were used to finance Axis 1 measures; the cost of permanent cessation was about $€ 166$ million.

According to the European Commission's ex-post evaluation [17] the measure involving permanent cessation was inefficient, because the objective of reducing overcapacity could have been reached by other management measures. The compensations envisaged for temporary cessation are also considered inefficient, because they were provided as a partial mitigation of the consequences of protracted stops. Only about 1600 fishers received socio-economic compensations in Italy. The figure was lower than expected and was due partly to the limited attractiveness of the sector to young fishers, to fishers' age, to the lack of real diversification opportunities and to the availability of other EU funds financing retraining. 
According to OpenCohesion data on the EFF impact on employment, the EU-level targets were not achieved (Table 8).

Table 8. Fisheries employment levels outcome indicators (OpenCohesion)

\begin{tabular}{l|c|l|l}
\hline Outcome indicators* & EU target value & Italy target value & Final value \\
\hline FLAG jobs created & 4,619 & 1,920 & 139 \\
\hline Fisheries jobs created & 6,930 & 3,200 & 111 \\
\hline FLAG jobs maintained & 26,530 & 23,099 & 355 \\
\hline Fisheries jobs maintained & 52,437 & 32,400 & 2,860
\end{tabular}

Source: https://cohesiondata.ec.europa.eu/2014-2020/ESIF-2014-2020-Achie vement-Details/aesb-873i

In general, jobs declined sharply during the EFF programming period (European Commission, 2017). The fact that the funds were channelled towards Priority axis 1, especially permanent cessation, clearly contributed to the job loss. The ex-post evaluation of the EFF highlights Priority axis 4, concerning the sustainable development of fisheries areas and the creation of fisheries local action groups (FLAGs). According to the "Study on the implementation of Axis 4 of the European Fisheries Fund" MARE/2011/01, Axis 4 seems to have contributed to preserve about 9,000 jobs and to create 6,000-8,000 more, although these data disagree with those of the EU OpenCohesion database. In Italy FLAGs began operating late; therefore, at variance with other Member States like Spain, they did not exert favourable effects on employment figures on fisheries value added.

It may thus be concluded that, as demonstrated by the indicators, the socioeconomic impacts of the CFP have not been mitigated by the measures funded by the EU despite the substantial outlay of the structural funds.

\section{Conclusion}

Eight years into the CFP and almost 10 since the adoption of the first national management plans for demersal trawl fisheries, the Mediterranean fish stocks are still exploited above the maximum sustainable yield [18]. The consistent overfishing is due to excessive effort. As a result, in the past 20 years the Italian fishing sector has undergone a reduction of fleet capacity and fishing effort, which has resulted inconsiderable job cuts. The 2018 update of the management plans for demersal trawl fisheries has also introduced effort regulation as the main technical measure.

The outcome of these policies has been a marked reduction in the volume and value of production in all areas from 2004 to 2017 [8]. The reduced production is due to the effort reduction as well as to economic factors (incidence of the energy cost), social problems (difficulty in finding specialized workers) and ecological issues (probable increase in the actual effort due to greater vessel efficiency and to increased fishing effort by the other Mediterranean fleets). 
Effort rationalization has not enhanced profitability for the remaining demersal trawlers.

The ex-post evaluation of the economic and social effectiveness of the measures of the national management plans 2011-2017 demonstrated their poor effectiveness, particularly in the economic sector. The negative value of the LEI is to be ascribed to the use of high RPs and to a general deterioration of the profit indicators, due essentially to reduced catches and labour productivity and to increased operating costs.

The ex-ante efficiency evaluation of the second-generation management measures (2018-2023) leads to expect a marked reduction in FTE jobs, particularly in2023, due to the progressive reduction of days at sea.

As regards the support provided by the structural funds, the sums allocated for permanent and temporary cessation and socio-economic compensations have proved inefficient and have not improved fishers' conditions despite the substantial outlays.

One of the factors hampering the achievement of the biological, but also economic and social, sustainability targets is the poor sharing of objectives among management bodies (European Commission and national and regional administrations). The modes of management plan implementation should lead to the creation of a body with specific roles and responsibilities in plan management, surveillance and monitoring. The governance should be inspired to recent approaches in this field, especially as regards co-management and responsive management, with a broader stakeholder involvement in management, surveillance and monitoring.

A further obstacle hampering the recovery of the sector is the poor fisher and owner awareness of the changes that have affected fisheries in the past few years; this results in their limited ability to address and adjust to such changes by adopting a more entrepreneurial stance based on continuous training and a greater use of investment. The levels of activity are progressively declining, also due to the adoption of the recent management measures (national and multiannual management plans); average productivity is slightly improving, but it will be able to achieve levels that ensure economic sustainability only if it is accompanied by a consistent effort reduction. The direct effects of these changes will be lower employment levels in terms of FTE; since the cost of labour is proportional to revenues, due to the widespread application of profit-sharing contracts, incomes may increase only in presence of increased daily value added. In Italy, several local operators have adopted quality labels, have created or strengthened the role of Producer Organizations or have undertaken direct sale, thus promoting commercial strategies that improve the traceability and quality of fresh local products. However, the distribution network and sales system is still inadequate and inefficient, also due to fishers' typical business risk aversion and to the near absence of training opportunities directed at up grading their skills, which would enable the adoption of new sales technologies, like the exploitation of digital markets.

Acknowledgements. The study was funded by Uila Pesca under the three-year national fishing plan, launched by the Fishery Directorate - Mipaaf. 


\section{References}

1. Caddy, J.F.: Practical issues in choosing a framework for resource assessment and management of Mediterranean and Black Sea fisheries. Medit. Mar. Sci. 10, 83-120 (2009). https://doi.org/10.12681/mms.124

2. Vielmini, I., Perry, A.L., Cornax, M.J.: Untying the Mediterranean Gordian knot: a twenty first century challenge for fisheries management. Front. Mar. Sci. 4, 195 (2017). https://doi. org/10.3389/fmars.2017.00195

3. Colloca, F., Scarcella, G., Libralato, S.: Recent trends and impacts of fisheries exploitation on Mediterranean stocks and ecosystems. Front. Mar. Sci. 4, 244 (2017). https://doi.org/10. 3389/fmars.2017.00244

4. Sabatella R.F., Spagnolo M.: National planning and management measures, Chap. 10. In: Cataudella, S., Spagnolo, M. (eds.), The State of Italian Marine Fisheries and Aquaculture. Ministero delle Politiche Agricole, Alimentari e Forestali (MiPAAF), Rome (Italy), 620 p. $(2011)$

5. Cardinale, M., Osio, G.C., Scarcella, G.: Mediterranean sea: a failure of the european fisheries management system. Front. Mar. Sci. 4, 72 (2017). https://doi.org/10.3389/fmars. 2017.00072

6. Sabatella, E.C., et al.: Key economic characteristics of Italian trawl fisheries and management challenges. Front. Mar. Sci. 4, 371 (2017). https://doi.org/10.3389/fmars. 2017.0037

7. EU COM: Commission Staff Working Paper, Impact Assessment, Accompanying the document, Commission proposal for a Regulation of the European Parliament and of the Council on the Common Fisheries Policy [repealing Regulation (EC) $N^{\circ}$ 2371/2002]. 425 final; SEC(2011) 892 final (2011)

8. Maiorano, P., Sabatella, R.F., Marzocchi, B.M. (eds.): Annuario sullo stato delle risorse e sulle strutture produttive dei mari italiani, 432 p. (2019)

9. Coppola, G., Gambino, M., Paolucci, C., Restaino, M.L.: The dynamics of the Italian maritime districts (2004-2013). In: XXIV Conference of the European Association of Fisheries Economists. Faculty of Geography, Santiago de Compostela, 2-4 April 2019 (2019)

10. MiPAAFT: Decreto Direttoriale n. 6 del 20 settembre 2011. Adozione dei piani nazionali di gestione della flotta (2011). https://www.politicheagricole.it/flex/cm/pages/ServeBLOB.php/ L/IT/IDPagina/6896

11. MiPAAFT: Decreto del Direttore Generale n. 26510 del 28 dicembre 2018. Modifica dei Piani di Gestione Nazionale relativi alle flotte di pesca per la cattura delle risorse demersali nell'ambito delle GSA 9, 10, 11, 16, 17, 18 e 19 (2018) https://www.politicheagricole.it/flex/ $\mathrm{cm} /$ pages/ServeBLOB.php/L/IT/IDPagina/13693

12. EC (European Commission): Impact Assessment Guidelines. SEC(2005) 791, updated in March 2006, Brussels (2006)

13. Malvarosa, L., et al.: Sustainability Impact Assessment (SIA) in fisheries: implementation in EU fishing regions. Mar. Policy 101, 63-79 (2019)

14. Gambino, M., et al.: Towards an integrated coastal zone management in campania region (Italy) a multidisciplinary approach to the analysis of coastal fishery activities and their socio-economic management. Procedia - Soc. Behav. Sci. 223, 342-348 (2016). https://doi. org/10.1016/j.sbspro.2016.05.239

15. SOCIOEC: Deliverable 5.6 - Rating (ex ranking) management measures at CS level (2015) 
16. European Commission: Evaluating EU Activities - A practical guide for the Commission services. Office for Official Publications of the European Communities, Luxembourg 110 p. (2004). ISBN 92-894-7928-0

17. European Commission: Ex post evaluation of the european fisheries fund. Publications Office of the European Union, Luxembourg (2017). ISBN 978-92-79-65193-9. https://doi. org/10.2771/798734

18. STECF: Scientific, Technical and Economic Committee for Fisheries (STECF) ñ Mediterranean assessments 2016 part 2 (STECF1706). Publications Office of the European Union, Luxembourg. EUR 28359 EN (2017). https://doi.org/10.2760/015005

Open Access This chapter is licensed under the terms of the Creative Commons Attribution 4.0 International License (http://creativecommons.org/licenses/by/4.0/), which permits use, sharing, adaptation, distribution and reproduction in any medium or format, as long as you give appropriate credit to the original author(s) and the source, provide a link to the Creative Commons license and indicate if changes were made.

The images or other third party material in this chapter are included in the chapter's Creative Commons license, unless indicated otherwise in a credit line to the material. If material is not included in the chapter's Creative Commons license and your intended use is not permitted by statutory regulation or exceeds the permitted use, you will need to obtain permission directly from the copyright holder. 